\title{
FATE OF ATMOSPHERIC DUST FROM MINING ACTIVITIES IN NEW CALEDONIA AND THE IMPACT ON THE NICKEL CONTENT OF LICHEN
}

\author{
ESTELLE ROTH ${ }^{1}$, EMMANUEL RIVIERE $^{1}$, JEREMIE BURGALAT $^{1}$, NADIA NGASSA $^{1}$, \\ YAYA DEMBELE ${ }^{1}$, MARIAM ZAITER $^{1}$, ABDEL CHAKIR ${ }^{1}$, CAMILLE PASQUET ${ }^{2}$, \\ RONAN PIGEAU² \& PEGGY GUNKEL-GRILLON ${ }^{2}$ \\ ${ }^{1}$ GSMA UMR CNRS 7331, University of Reims Champagne Ardenne, France \\ 2ISEA, University of New Caledonia, Canada
}

\begin{abstract}
Nickel mining in New Caledonia proceeds in open pit mining. Therefore, bare soil surfaces submitted to wind blow and mining operation (earthwork, excavating, transport, etc.) are a source of particulate matter. These phenomena produce essentially coarse metal rich dusts which undergo regional atmospheric transport. This study aims to determine how the mining activities can impact the environment and the population in conjunction with the presence of particles in the atmosphere via the wind transport. In this work, Koniambo (KNS) is the target mine, a new plant and mining site created in 2010 in the north of New Caledonia. Particle matter with diameter below $10 \mu \mathrm{m}\left(\mathrm{PM}_{10}\right)$ was measured in three sites surrounding the KNS mine to follow the population exposition to particulate matter. Air mass trajectory modelling was carried out to identify the sources of high $\mathrm{PM}_{10}$ events (above $50 \mu \mathrm{g} / \mathrm{m}^{3}$ ) in these locations and to elaborate a density map of air mass trajectories. Five mines appeared to contribute more or less to rich $\mathrm{PM}_{10}$ air masses: KNS, Népoui, Poro, Kouaoua and Monéo. A density map of air mass trajectories originating from these mines showed areas where the lower atmosphere is potentially impacted by mining dust. As lichens are known for their air pollution bioindication properties, lichens were sampled in areas with high, medium and poor trajectory densities and their $\mathrm{Ni}$ and Ti content were analyzed. A positive correlation between Ni/Ti ratio and trajectory densities was observed. Air mass trajectory modelling is thus a good tool to predict the potential environmental impact of mining dust.
\end{abstract}

Keywords: particulate matter, atmospheric modelling, bioindication, lichen, nickel, mining.

\section{INTRODUCTION}

Nickel is a very needed metal especially because it is a constituent of stainless steel. New Caledonia is the fourth producer of nickel thanks to its ultramafic weathered soils. Nickel mining in New Caledonia proceed in opencast mines. Thus mining operation (earthwork, excavating, transport, etc.) are source of particulate matter and bare soil surfaces are submitted to wind blow [1], [2]. These origins produce essentially coarse dusts with diameter above $1 \mu \mathrm{m}$ with a size distribution centred on $10 \mu \mathrm{m}$ [3]. These dusts are eliminated from the atmosphere by sedimentation in a few minutes to a few hours [4]. Mining particles are known to present high potential risks to environment and human health especially because their potential high content in metal ( $\mathrm{Hg}, \mathrm{Pb}, \mathrm{As}, \mathrm{Cr}, \mathrm{Ni}$, etc.) [5]-[9]. Lichen bioindication is a widely used method for the study of the dry and wet particle settling area and for identifying pollutions sources [10]-[12], because, due to the absence of root system, lichen is sensitive to their atmospheric environment. They accumulate pollutants, especially metals [10], [12], [13]. To avoid measurement bias linked to the age and species of lichens, the measured metal concentrations have to be normalized by dividing them by the simultaneously measured concentration of a reference element, such as $\mathrm{Al}$, $\mathrm{Sc}$, or $\mathrm{Ti}$, of exclusively crustal origin and not emitted in air by human activity [10], [14]. 
A new plant and mining site, Koniambo (KNS), was created in 2010 in the North of New Caledonia. This study aims to determine how the mining activities of KNS can impact the environment and the populations related to the presence of particle in the atmosphere on a regional scale via the wind transport. $\mathrm{PM}_{10}$ were measured in three sites surrounding the new mining site to follow the population exposition to particulate matter. Atmospheric modelling, through air mass trajectory calculations, was used to identify the potential sources of high particle matter events in these locations. Maps of air masses trajectories density were computed to identify places likely to be impacted. Lichens were sampled in the North of New Caledonia and their Ni and Ti content were analyzed and correlated to trajectory densities.

\section{MATERIALS AND METHODS}

\subsection{Particulate matter sampling site}

KNS is a recent mining exploitation with a Ni smelter in the north of New Caledonia near Koné. The earthwork began in 2010 and the extraction of nickel lateric ores in 2013. Three crowded sites around the mine were selected to measure particulate matter $\mathrm{PM}_{10}$ to see whether the population was exposed to mining dust: Gatope, Oundjo, Voh (Fig. 1). $\mathrm{PM}_{10}$ were measured each quarter using a MP101M sampler provided by Environnement SA over 2014.
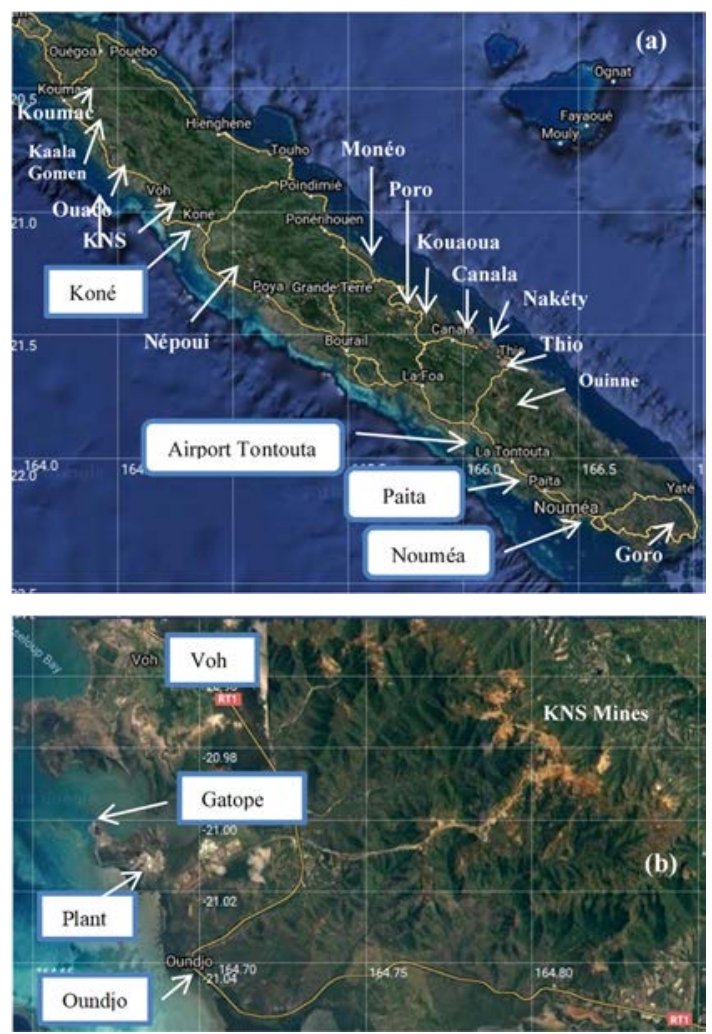

Figure 1: (a) Mines (white), principal towns (white square); and (b) $\mathrm{PM}_{10}$ sampling sites (Gatope, Oundjo, Voh). 


\subsection{Lichen sampling}

Lichen belonging to the Parmeliaceae family were collected at about 1-1.5 meters above the ground using pre-cleaned plastic knives and placed in closed individual plastic bags.

In the laboratory, lichens were dried at $45^{\circ} \mathrm{C}$ overnight. If present, bark was removed before lichens were crushed in a pre-cleaned agate mortar to obtain a fine and homogeneous powder. Around $100 \mathrm{mg}$ of powdered lichen, precisely weighed was placed in a PTFE beaker (Savilex) with $2 \mathrm{~mL}$ each of suprapure $\mathrm{HCl}, \mathrm{HNO}_{3}$ and $1 \mathrm{~mL}$ of $\mathrm{HF}$. This mixture was heated at $105^{\circ} \mathrm{C}$ until complete digestion.

Quality of the analytical data was assessed by blanks and biological samples with known content such as lichens (BCR-482) and grass (WEPAL, NL) processed in parallel of each batch of unknown samples.

Solutions, adequately diluted with Milli-Q water, were analysed for Ni and Ti using an Inductively Coupled Plasma-Optical Emission Spectrometry (ICP OES 730ES VARIAN). Limits of detection (LOD) were evaluated using three times the standard deviation of five analytical blanks (Table 1). Measurements for most elements did not differ by more than $20 \%$ from certified values (Table 1).

\subsection{Air mass trajectory modelling approach}

In order to identify potential sources of high $\mathrm{PM}_{10}$ sampled at the three above-mentioned sites and bring to the fore the most impacted areas by the mining sources, an air-mass trajectory analysis was carried out using FLEXTRA [15]. It is fed by meteorological operational analyses (winds, orography, humidity) of the European Centre for Medium Range Weather Forecast (ECMWF) every 6 hours in a grid domain of $0.2^{\circ}$ latitude/longitude horizontal resolution encompassing New Caledonia. The model can compute backward trajectories to check the origin of an air mass, or forward trajectories to check what an air mass originated from a pollution source can become. Several modes of trajectory calculation can be set by the user, and in our study, we were computing either clusters or trajectories of individual trajectories. All the trajectories computed in this study were initialized at $10 \mathrm{~m}$ above the ground with a 3 dimension computing mode. They were all $12 \mathrm{~h}$ long. The time resolution of each individual trajectory was 10 minutes. Trajectories density maps were established to highlight the most influential mining sites.

Once $\mathrm{PM}_{10}$ sources were identified, a series of forward trajectories from each source was computed during a long period and a trajectory density card, accounting for all the identified source was established to identify areas the most impacted by air masses. Trajectory density maps are maps expressed in pixels in which the ratio of trajectories going over the pixel to the total trajectory number are reported. Thus, it highlights the most impacted locations by the mining sources. Trajectory densities within a specific area were finally linked to the nickel content of lichen sampled in this area.

Table 1: Limit of detection (LOD) and quality control of the analyses.

\begin{tabular}{|c|c|c|c|c|c|}
\hline \multirow{2}{*}{} & LOD $(\mathrm{mg} / \mathrm{kg})$ & \multicolumn{2}{|c|}{ BCR482 $(\mathrm{mg} / \mathrm{kg})$} & \multicolumn{2}{c|}{ Grass $(\mathrm{mg} / \mathrm{kg})$} \\
\cline { 2 - 6 } & & Certified & Measured & Certified & Measured \\
\hline $\mathrm{Ni}$ & 0.01 & 2.47 & 2.97 & 0.83 & $<$ LOD \\
\hline $\mathrm{Ti}$ & 0.001 & $-^{\mathrm{a}}$ & 85.8 & $15.8^{\mathrm{b}}$ & 16.1 \\
\hline
\end{tabular}

${ }^{a}$ to the best of our knowledge; ${ }^{b}$ provided but not certified. 


\section{RESULTS AND DISCUSSION}

\subsection{Particulate matter}

Year averages were calculated in the three $\mathrm{PM}_{10}$ sampling points (Fig. 1(b), Table 2). Average concentrations of particulate matter in places surrounding Koniambo are between 10 and $16 \mu \mathrm{g} / \mathrm{m}^{3}$ (Table 2).

Year averages are associated with very high standard deviations, especially in Gatope and Oundjo, meaning that, in these locations, high particulate events such as local outdoor fires and cooking may take place. Comparing $\mathrm{PM}_{10}$ year averages in these three stations with absolute annual average of $\mathrm{PM}_{10}$ in European natural, rural, near city, urban and kerbside sites, we can assume that average $\mathrm{PM}_{10}$ are low and in the range of natural to rural typical concentrations [16]. As their impact depends on their nature, low levels do not mean that particles are safe for human and environment.

\subsection{Source identification}

Backward trajectories from $\mathrm{PM}_{10}$ sampling points were simulated over 2014 and screened to identify potential sources using density maps. Trajectory densities were computed for different $\mathrm{PM}_{10}$ ranges $\left(<10,10-20,20-30,30-40,40-50,>50 \mu \mathrm{g} / \mathrm{m}^{3}\right)$ for selected potential sources including towns (Koné, Païta, Tontouta airport, Nouméa) and open pit mines (KNS, Kouaoua, Monéo, Thio, Canala, Nakéty, Népoui, Ouinne, Poro, Ouaco, Goro, see Fig. 1(a)). Percentages of air masses overflying potential sources for different $\mathrm{PM}_{10}$ ranges recorded in Gatope, Voh and Oundjo are reported in Fig. 2.

The selected potential sources only explain $85 \%, 50 \%$ and $25 \%$ of the total air masses arriving at Gatope, Voh and Oundjo, respectively (Fig. 2). The complementary percentage might be due to local PM production such as local transport inducing road particles suspending, wood fire especially in Oundjo.

For Gatope $\mathrm{PM}_{10}$ sampling station, more than $55 \%$ of air masses overflew Koné, Népoui and KNS because they are swept by south-west/north-east dominating winds (Fig. 2).

Nouméa is as well on the major dominating winds but only $5 \%$ of air masses contributes to the air mass density due to further distance to $\mathrm{PM}_{10}$ sampling points. When overflying Koné and Népoui, air masses sampled in Gatope have a great probability to be associated with high particle pollution since more than $15 \%$ of them are associated with $\mathrm{PM}_{10}$ recordings over $40 \mu \mathrm{g} / \mathrm{m}^{3}$. As they are on the same wind trajectories, we cannot prove whether the town (Koné) or the mine (Népoui) is the principal contributor of PM. KNS is a lower contributor to Gatope than Népoui because Gatope is on the east of Koniambo mine.

Voh is especially impacted by air masses originating from KNS (25\%) (Fig. 2) due to its upwind proximity from Voh, with more than $12 \%$ of the overall trajectories associated with $\mathrm{PM}_{10}$ over $40 \mu \mathrm{g} / \mathrm{m}^{3}$ (Fig. 2). Nevertheless, there is no clear discrimination in the particle concentration range. However, even if $\mathrm{PM}_{10}$ levels are not high, it does not exclude their potential impact on the environment with respect to the heavy metal content in the particles.

Table 2: 2014 year averages of $\mathrm{PM}_{10}$ in the three sampling points.

\begin{tabular}{|c|c|c|c|}
\hline \multirow{2}{*}{} & \multicolumn{3}{|c|}{ Sampling site } \\
\cline { 2 - 4 } & Gatope & Oundjo & Voh \\
\hline $\mathrm{PM}_{10}\left(\mu \mathrm{g} / \mathrm{m}^{3}\right)$ & $11.0 \pm 83.2$ & $16.8 \pm 87.6$ & $10.4 \pm 8.8$ \\
\hline
\end{tabular}




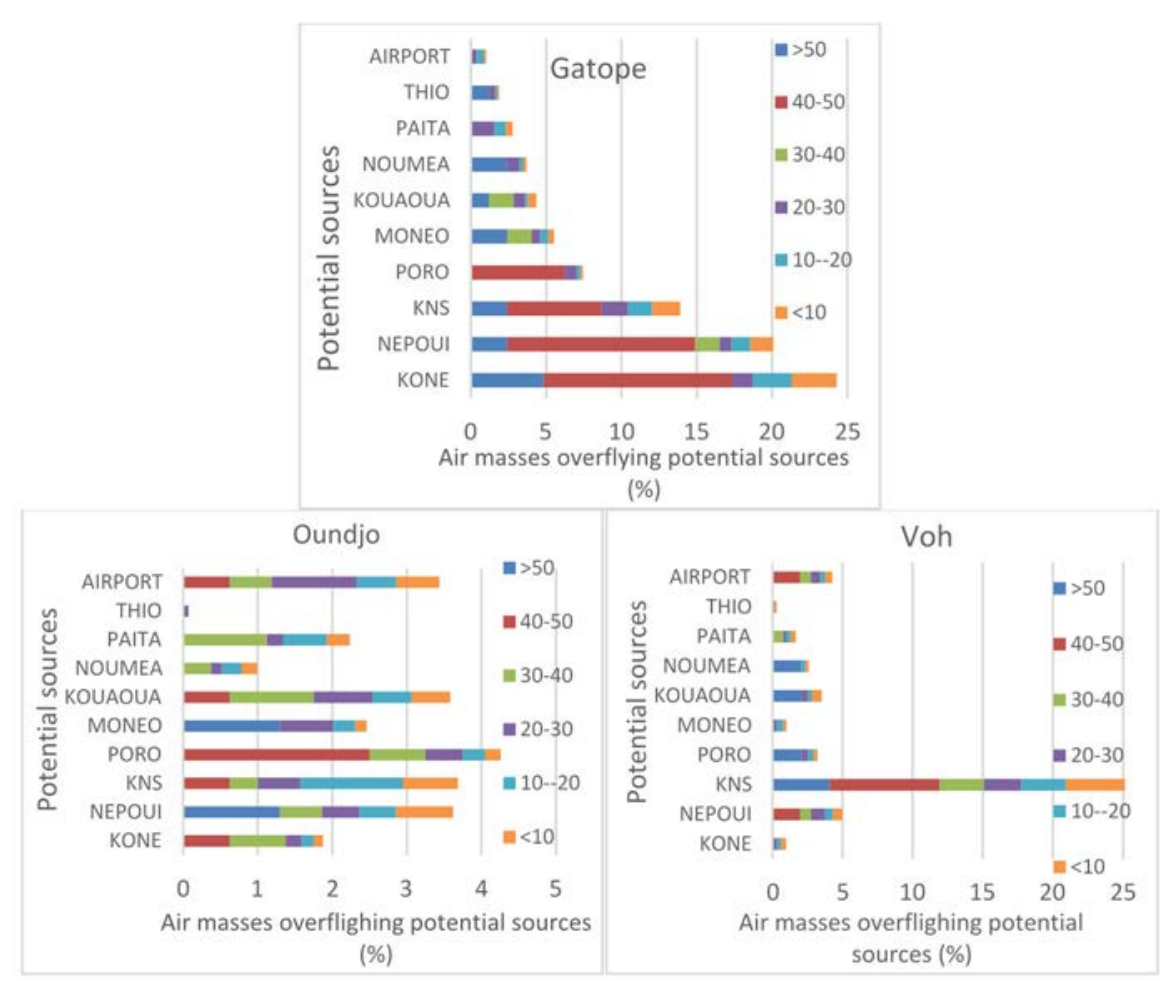

Figure 2: Percentages of air masses overflying screened sources resulting in different $\mathrm{PM}_{10}$ ranges in Gatope, Oundjo and Voh throughout 2014.

Oundjo is poorly impacted by selected potential sources since their contributions are lower than 5\% especially due to its position located in the south-east of Koniambo mine (Fig. 2). It may highlight that high $\mathrm{PM}_{10}$ events sampled at Oundjo station are from local origin.

The three $\mathrm{PM}_{10}$ sampling stations are also downwind air masses crossing New Caledonia from east to west and thus sweeping especially the mines of Poro, Monéo and Kouaoua. Other mines and towns are minor contributors.

\subsection{Density of trajectories issued from principal identified sources}

Contribution of principal potential sources identified previously (KNS, Népoui, Kouaoua, Poro, Monéo, Nouméa, Koné) in the air pollution of several locations around Koniambo were established (Fig. 3).

Fig. 3 shows that Tiéta and Temala are the locations with the highest densities of air masses from previously identified potential sources. Ouahat, Boyen, Voh and Voh-Tieta have similar trajectory densities. For these locations, the higher source contribution is from KNS, followed by Koné and Népoui. Tiéta and Temala show higher contribution of KNS in resulting air mass density since they are really close to KNS and under the dominating wind. Gatope, Oundjo and Voh are less impacted by air masses originated from KNS than Tiéta and Temala since they are on the left side of KNS. For other locations with densities lower than the one of Voh, the relative contribution of sources is more distributed, with contributions from Népoui, KNS and Koné of the same order (Fig. 3). 


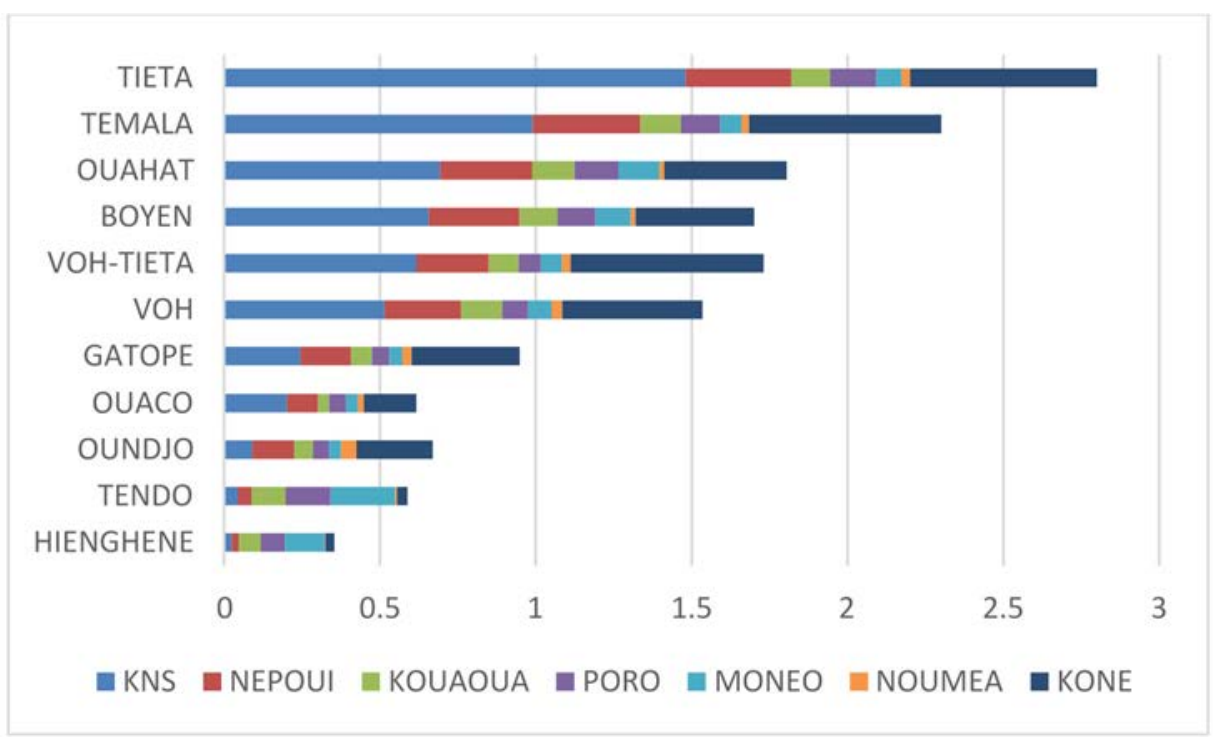

Figure 3: Mine and town contribution in air masses overflying lichen sampling area.

For the two locations in the North West side of New Caledonia, the contribution of Monéo is the most important, since Monéo is also on the west coast. The global contribution of mines located on the east coast of New Caledonia (Poro, Monéo, Kouaoua) is not to neglect for location in the middle and in the west of New Caledonia.

Nouméa has a more negligible contribution than other studied sources due to further distance from sampling points (Fig. 3).

\section{4 $\mathrm{Ni}$ content of lichen}

Lichen were sampled next to tribe's locations and labelled as the tribe's name. Nickel and titanium levels range between $5-347 \mathrm{mg} / \mathrm{kg}$ and $31-2348 \mathrm{mg} / \mathrm{kg}$, respectively leading to $\mathrm{Ni} / \mathrm{Ti}$ ratios between 0.02 to 1.01 (Table 3). Background concentration in lichens are between 0 and $5 \mathrm{mg} / \mathrm{kg}$ [17], but near urban/industrial areas ten times higher values can be detected [12], [18]. In ultramafic regions, levels as up to $6000 \mathrm{mg} / \mathrm{kg}$ have already been detected in lichen on mining sites [13].

\subsection{Link between trajectory densities from identified sources and Ni content of lichen}

Forward trajectories from major contributing mines (Népoui, KNS, Poro, Monéo and Kouaoua) were computed to identify areas swept by air masses from these sources and potentially charged in mining particles (Fig. 4).

The examination of dense areas overflown by the air masses originated from mines allowed to determine zones potentially highly (Tiéta, Témala, Ouahat, etc.), moderately (Ouahat, Boyen) and less (Oundjo, Gatope, Ouaco, Hienghène, Tendo) impacted by mining activities (Fig. 3). Lichens were sampled in these locations to study whether there was a link between air mass density and nickel content.

Ratio Ni/Ti were plotted as a function of the trajectory densities computed in the lichen sampling area (Fig. 5). 
Table 3: Lichen name and location and content in nickel and titanium.

\begin{tabular}{|c|c|c|c|c|c|c|}
\hline Lichen location & Latitude & Longitude & $\begin{array}{c}\mathrm{Ni} \\
(\mathrm{mg} / \mathrm{kg})\end{array}$ & $\begin{array}{c}\mathrm{Ti} \\
(\mathrm{mg} / \mathrm{kg})\end{array}$ & $\mathrm{Ni} / \mathrm{Ti}$ & Average $\mathrm{Ni} / \mathrm{Ti}$ \\
\hline \multirow{2}{*}{ Boyen } & -20.8455 & 164.7022 & 116 & 115 & 1.01 & \multirow{2}{*}{$0.72 \pm 0.41$} \\
\hline & -20.8204 & 164.6163 & 52 & 123 & 0.42 & \\
\hline \multirow{2}{*}{ Gatope } & -20.9678 & 164.6593 & 71 & 563 & 0.13 & \multirow{2}{*}{$0.14 \pm 0.02$} \\
\hline & -20.9678 & 164.6593 & 67 & 423 & 0.16 & \\
\hline \multirow{2}{*}{ Hienghene } & -20.6273 & 164.8762 & 25 & 1298 & 0.02 & \multirow{2}{*}{$0.03 \pm 0.01$} \\
\hline & -20.6273 & 164.8762 & 19 & 570 & 0.03 & \\
\hline \multirow{3}{*}{ Ouaco } & -20.8342 & 164.4710 & 347 & 2348 & 0.15 & \multirow{3}{*}{$0.17 \pm 0.03$} \\
\hline & -20.8343 & 164.4710 & 136 & 668 & 0.20 & \\
\hline & -20.8343 & 164.4710 & 109 & 682 & 0.16 & \\
\hline \multirow{3}{*}{ Ouahat } & -20.8484 & 164.7021 & 24 & 53 & 0.46 & \multirow{3}{*}{$0.34 \pm 0.20$} \\
\hline & -20.8484 & 164.7021 & 35 & 78 & 0.44 & \\
\hline & -20.8484 & 164.7021 & 7 & 63 & 0.11 & \\
\hline \multirow{2}{*}{ Oundjo } & -21.0349 & 164.7026 & 32 & 340 & 0.09 & \multirow{2}{*}{$0.16 \pm 0.10$} \\
\hline & -21.0349 & 164.7026 & 26 & 110 & 0.23 & \\
\hline \multirow{3}{*}{ Temala } & -20.8878 & 164.6830 & 20 & 74 & 0.27 & \multirow{3}{*}{$0.31 \pm 0.05$} \\
\hline & -20.8878 & 164.6830 & 40 & 128 & 0.32 & \\
\hline & -20.8878 & 164.6830 & 21 & 60 & 0.36 & \\
\hline \multirow{3}{*}{ Tendo } & -20.7134 & 164.8167 & 5 & 31 & 0.15 & \multirow{3}{*}{$0.11 \pm$} \\
\hline & -20.7134 & 164.8168 & 6 & 49 & 0.12 & \\
\hline & -20.7134 & 164.8168 & 6 & 117 & 0.05 & \\
\hline \multirow{2}{*}{ Tiéta } & -20.9170 & 164.7457 & 34 & 35 & 0.97 & \multirow{2}{*}{$0.64 \pm 0.46$} \\
\hline & -20.9170 & 164.7457 & 16 & 50 & 0.32 & \\
\hline \multirow{3}{*}{ Voh } & -20.9494 & 164.6883 & 128 & 311 & 0.41 & \multirow{3}{*}{$0.43 \pm 0.01$} \\
\hline & -20.9494 & 164.6883 & 87 & 202 & 0.43 & \\
\hline & -20.9494 & 164.6883 & 237 & 541 & 0.44 & \\
\hline Voh-Tieta & -20.9500 & 164.7056 & 166 & 251 & 0.66 & 0.66 \\
\hline
\end{tabular}

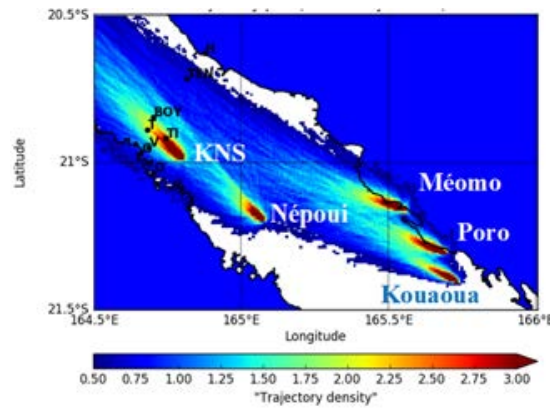

(a)

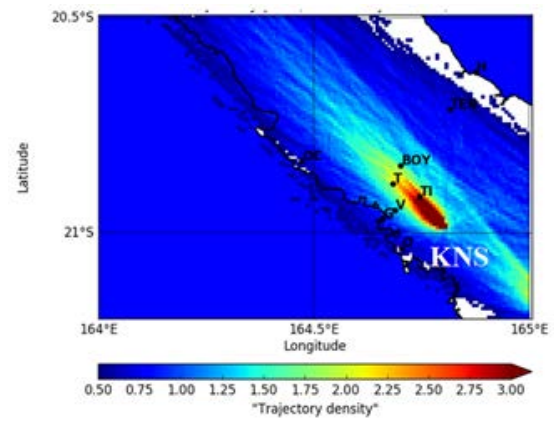

(b)

Figure 4: Density (in \%) of air mass trajectories originated from principal contributing mines Népoui (M-N), KNS (M-kns), Poro (M-P), Monéo (M-M) and Kouaoua (M-K) throughout 2014. (a) Point of lichen sampling $(\mathrm{H}=$ Hienghène, $\mathrm{TEN}=$ Tendo, $\mathrm{B}=$ Boyen, $\mathrm{OH}=$ Ouahat, $\mathrm{T}=$ Temala, $\mathrm{TI}=$ Tiéta, $\mathrm{V}=\mathrm{Voh}, \mathrm{G}=$ Gatope, $\mathrm{O}=$ Oundjo, $\mathrm{OC}=$ Ouaco); and (b) Zoomed in. 


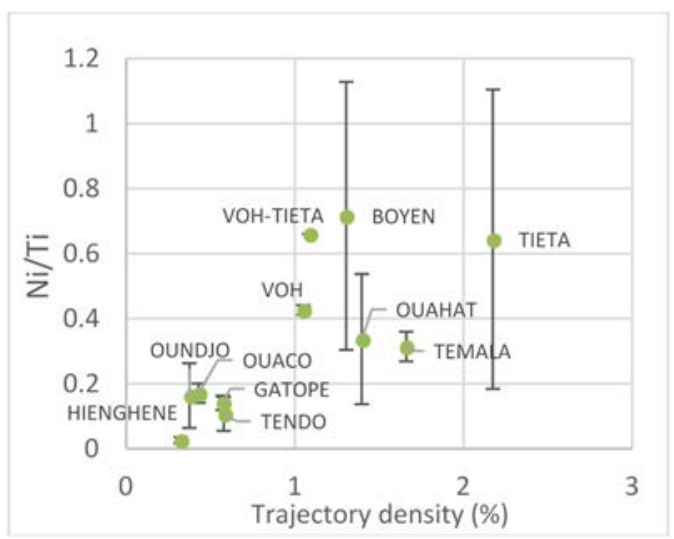

Figure 5: Mine contribution in air masses overflying lichen sampling area.

Fig. 5 shows a positive correlation between the ratio $\mathrm{Ni} / \mathrm{Ti}$ and the trajectory densities from mines. Two groups of lichens can be defined in link with their Ni/Ti and trajectory density: the first for $\mathrm{Ni} / \mathrm{Ti}<0.2$ and trajectory densities below $1 \%$ and the second for $\mathrm{Ni} / \mathrm{Ti}$ $>0.2$ and trajectory densities $>1 \%$. Lichens sampled near west coast (Oundjo, Ouaco, Gatope) and the east coast (Hienghène) and in Tendo belong to the first group. The other lichens were sampled in the wind field sweeping KNS and Népoui mines resulting in higher $\mathrm{Ni} / \mathrm{Ti}$ contents. The proximity of mines and the dominating wind field are key parameters in nickel spreading in the environment.

\section{CONCLUSION}

Backward trajectories associated with Potential Source Contribution Function, Residence Time Analysis and Cluster Analysis Technique have already been used to evaluate the origin of atmospheric pollutants [19], [20]. Lots of them use Lagrangian trajectory models like HYSPLIT and FLEXPART relying on meteorological fields [21]. Herein we have coupled trajectory densities obtained thanks to the FLEXTRA trajectory model with $\mathrm{PM}_{10}$ measurements and results of normalized lichen content in nickel. It allowed us to study the impact of open pit mining next to Koniambo, a recent mining site in the north of New Caledonia. To follow the population exposure to particles, $\mathrm{PM}_{10}$ were recorded in Tribes around Koniambo. The study of the origin of $\mathrm{PM}_{10}$ for different ranges of $\mathrm{PM}_{10}$ concentration showed that open pit mines can contribute to dispersion of nickel in the environment. Mines that may contribute to $\mathrm{PM}_{10}$ levels in this area were identified to be the nearest ones present in the dominating wind fields (KNS and Népoui) but also some from the opposite coast (Monéo, Poro and Kouaoua). Trajectory densities maps from these mines allowed to identify that the more exposed tribes are in Teméla and Tiéta. Lichen were sampled at these locations as well as in less exposed area and their content in $\mathrm{Ni}$ and $\mathrm{Ti}$ were analyzed. Results showed that $\mathrm{Ni} / \mathrm{Ti}$ ratio was linked to the trajectory densities originated from the identified mines. The proximity of mines and the dominating wind field seem to be the key parameters in nickel spreading in the environment. Lichen bioindication provides the mining impact perimeter on the environment linked to dry and wet deposition. However, the impact perimeter on health linked to the presence of PM containing trace metal elements might be higher. 


\section{ACKNOWLEDGEMENT}

The authors thank the CNRT project "Dispersion des métaux de la mine au lagon".

\section{REFERENCES}

[1] Chakraborty, M., Ahmad, M., Singh, R., Pal, D., Bandopadhyay, C. \& Chaulya, S., Determination of the emission rate from various opencast mining operations. Environ. Model. Softw., 17, pp. 467-480, 2002.

[2] Huertas, J.I., Huertas, M.E., Izquierdo, S. \& González, E.D., Air quality impact assessment of multiple open pit coal mines in northern Colombia. J. Environ. Manage., 93, pp. 121-129, 2012.

[3] Csavina, J. et al., A review on the importance of metals and metalloids in atmospheric dust and aerosol from mining operations. Science of the Total Environment, 433, pp. 58-73, 2012.

[4] Seinfeld, J.H. \& Pandis, S.N., Atmospheric Chemistry and Physics: From Air Pollution to Climate Change, Wiley \& Sons: New York, 2006.

[5] Meza-Figueroa, D. et al., The impact of unconfined mine tailings in residential areas from a mining town in a semi-arid environment: Nacozari, Sonora, Mexico. Chemosphere, 77, pp. 140-147, 2009.

[6] Brotons, J.M., Diaz, A.R., Sarria, F.A. \& Serrato, F.B., Wind erosion on mining waste in Southeast Spain. Land Degrad. Dev., 21, pp. 196-209, 2010.

[7] Csavina, J. et al., Metals and metalloids in atmospheric aerosols from mining operations. Water, Air, Soil Pollut., 221, pp. 145-157, 2011.

[8] Corriveau, M.C., Jamieson, H.E., Parson, M.B., Campbell, J.L. \& Lanzirotti, A., Direct characterization of airborne particles associated with arsenic-rich mine tailings: Particle size, mineralogy and texture. Appl. Geochem., 26, pp. 1639-1648, 2011.

[9] Querol, X., Alastuey, A., Lopez-Soler, A. \& Plana, F., Levels and chemistry of atmospheric particulates induced by a spill of heavy metal mining wastes in the Donana area, Southwest Spain. Atmos. Environ., 34, pp. 239-253, 2000.

[10] Monna, F., Bouchaou, L., Rambeau, C. \& Losno, R., Lichens used as monitors of atmospheric pollution around Agadir (southwestern Morocco): A case study predating lead-free gasoline. Water, Air, Soil Pollut., 223, pp. 1263-1274, 2012.

[11] Nimis, P.L., Castello, M. \& Perotti, M., Lichens as bioindicators of heavy metal pollution: A case study at La Spezia (N Italy). Plants as Biomonitors. Indicators for Heavy Metals in the Terrestrial Environment, ed. B. Markert, VCH Weinheim: New York, Basel and Cambridge, pp. 265-284, 1993.

[12] Conti, M.E. \& Cecchetti, G., Biological monitoring: Lichens as bioindicators of air pollution assessment: A review. Environmental Pollution, 114, pp. 471-492, 2001.

[13] Pasquet, C. et al., Impact of nickel mining in New Caledonia assessed by compositional data analysis of lichens. SpringerPlus, 5(1), pp. 20-22, 2016.

[14] Dongarra, G., Ottomello, D., Sabatino, G. \& Triscari, M., Use of lichens in detecting environmental risk and in geochemical prospecting. Environmental Geology, 26, pp. 139-146, 1995.

[15] Stohl, A., Computation, accuracy and applications of trajectories: A review and bibliography. Atmos. Environ., 32, pp. 947-966, 1998.

[16] Putaud, J. et al., A European aerosol phenomenology 2 : Chemical characteristics of particulate matter at kerbside, urban, rural and background sites in Europe b. Atmos. Env., 38, pp. 2579-2595, 2004. 
[17] Zvěřina, O., Láska, K., Červenka, R., Kuta, J., Coufalík, P. \& Komárek, J., Analysis of mercury and other heavy metals accumulated in lichen Usnea Antarctica from James Ross Island, Antarctica. Environ. Monit. Assess., 186, pp. 9089-9100, 2014.

[18] Aslan, A., Gurbuz, H., Yazici, K., Cicek, A., Turan, M. \& Ercisli, S., Evaluation of lichens as bio-indicators of metal pollution. J. Elementol., 18(3), pp. 353-369, 2012.

[19] Karaca, F.A. \& Alagha, I.O., Long-range potential source contributions of episodic aerosol events to $\mathrm{PM}_{10}$ profile of a megacity. Atmos. Environ., 43(36), pp. 5713-5722, 2009.

[20] Lee, S. \& Ashbaugh, L., Comparison of multi-receptor and single-receptor trajectory source 563 apportionment (TSA) methods using artificial sources. Atmos. Environ., 41, pp. 1119-1127, 2007.

[21] Fleming, Z.L., Monks, P.S. \& Manning, A.J., Review: Untangling the influence of airmass history in 536 interpreting observed atmospheric composition. Atmos. Res., 104, pp. 1-39, 2012. 